\title{
FORGÓBORONA MUNKAESZKÖZÉNEK KINEMATIKAI VIZSGÁLATA
}

\section{RESEARCH ABOUT THE KINEMATICS OF THE ROTARY HARROW'S WORKING TOOL}

\author{
Pásztor Judit ${ }^{1}$, Forgó Zoltán ${ }^{2}$ \\ ${ }^{I}$ Sapientia Erdélyi Magyar Tudományegyetem, Müszaki és Humántudományok Kar I \\ Târgu Mureş, 540485, O.p. 9, C.p. 4, Şoseaua Sighişoarei 1C., Tel.: +40 265208 \\ 170, Fax: +40265206 211,E-mail:pjudit@ms.sapientia.ro \\ ${ }^{2}$ Sapientia Erdélyi Magyar Tudományegyetem, Müszaki és Humántudományok Kar $/$ \\ Târgu Mureş, 540485, O.p. 9, C.p. 4, Şoseaua Sighişoarei 1C., Tel.: +40 265208 \\ 170, Fax: +40265206 211, E-mail: zforgo@ms.sapientia.ro
}

\begin{abstract}
The preparation of the seedbed represents an essential work for the growth and development of plants. It is an important consumer of energy. The rotary harrow is meant to carry out of the preparing the seedbed. In this paper we study the kinematics of the rotary harrow's tools.
\end{abstract}

Keywords: rotary harrow, kinematics, trajectory, velocity, acceleration.

\section{Összefoglalás}

A termesztendő növények talajának előkészítése nagyon fontos mủvelet. A gépek munkája hatással van a talaj fizikai-mechanikai tulajdonságaira, közvetve a növényekre, ezért megválasztásuk és üzemeltetésük nagy körültekintést igényel. A forgóborona egy aktív magágy-előkészítő munkagép. Dolgozatunkban meghatározzuk a forgóborona munkaeszközeinek kinematikai egyenleteit.

Kulcsszavak: forgóborona, kinematika, pályagörbe, sebesség, gyorsulás.

\section{Bevezetés}

A talajművelés mechanikai beavatkozás, célja a termesztendő növény számára kedvező talajállapot kialakítása. A talajmüvelés alapmüveletekre, magágy-előkészítésre és tarlómunkákra osztható. A magágyelőkészítés a legigényesebb beavatkozás.

A forgóborona a magágy-előkészítés munkagépe. Munkája során a talaj aprítását végzi. Aprítás közben lazít, egyenget és erőteljesen kever is. A forgóborona kényszerhajtású, munkaeszközei aktívak. Vontatás közben az erőgép teljesítmény-leadó- tengelyéről, a TLT-ről is kapnak hajtást. Így kevesebb a munkagép vonóerő-igénye, kisebb a vontatásnál jelentkező csúszási veszteség, ezért nedvesebb talajviszonyok közt is alkalmazható [1].

$\mathrm{Az}$ gépüzemeltetés mindenkori célja a növény által igényelt magágy lehető legkevesebb menetszámmal és kedvező energiafelhasználással való biztosítása. A mozgáspályák matematikai modellezése alapján tanulmányozható a munkaeszköz mozgása, [5]. 


\section{A forgóboronafog kinematikai egyenletei}

A forgóborona munkaeszköze az 1 boronafog. A boronafogak páronként egy vízszintes tárcsára vannak erősítve, egy függőleges tengely körül forognak a 2-es fogaskerék segítségével, 1. ábra, [1].

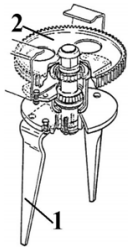

1. ábra. A forgóborona munkaeszköze [1]

A munkaeszközök hajtása az erőgép teljesítmény-leadó tengelyéröl történik, lassító áttételen keresztül, 2. ábra. A TLT tengely fordulatszáma egyezményes, 540 ford/min. A hajtásláncolatot úgy alakították ki, hogy a traktor-TLT-ről érkező forgó mozgását fogaskerekek közvetítik a függőleges tengelyekhez, így a szomszédos müvelőeszközök ellentétesen forognak.

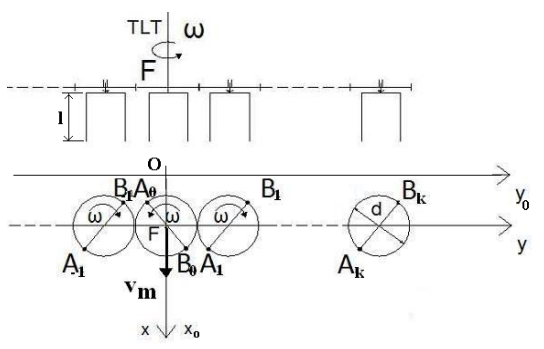

2. ábra. A forgóborona felépitése

$\mathrm{Az} \mathrm{A}_{\mathrm{k}}\left(\mathrm{x}_{\mathrm{Ak}}, \mathrm{y}_{\mathrm{Ak}}, \mathrm{z}_{\mathrm{Ak}}\right), \mathrm{B}_{\mathrm{k}}\left(\mathrm{x}_{\mathrm{Bk}}, \mathrm{y}_{\mathrm{Bk}}, \mathrm{z}_{\mathrm{Bk}}\right)$, pontok egy müvelöeszköz boronafogainak hegyét jelképezik. A szerszámok talajba nyúló részei a forgó és haladó mozgás együttes hatására mozdulnak el. Az ugyanazon múvelöeszköz boronafogai egymáshoz képest $180^{\circ}$-os szögeltolódással, a szomszédos müvelőeszköz boronafogai $90^{\circ}$, illetve $270^{\circ}$-os eltolódással mozognak, 3. ábra.

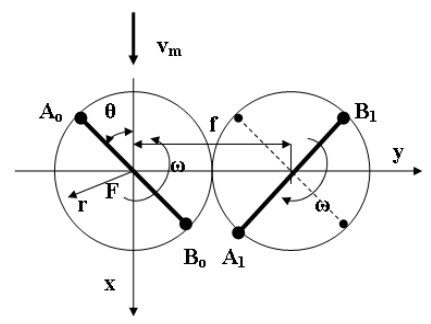

3. ábra. Forgóborona-fogcsúcs kinematikája

A boronafogak csúcsait $A_{k}\left(x_{A k}, y_{A k}, z_{A k}\right)$, $B_{k}\left(x_{B k}, y_{B k}, z_{B k}\right)$ jelölésekkel jelöltük. Az $A_{0}\left(x_{A 0}, y_{A 0}, z_{A 0}\right), \quad B_{0}\left(x_{B 0}, y_{B 0}, z_{B 0}\right)$ pontokkal sorszámozott müvelőeszközt tekintjük a TLT-ről meghajtott müvelőeszköznek.

$A_{k}\left(x_{A k}, y_{A k}, z_{A k}\right), B_{k}\left(x_{B k}, y_{B k}, z_{B k}\right)$ pontok kinematikai egyenleteit általánosítva adjuk meg. Így alkalmazhatók változó számú müvelöszerszámmal szerelt forgóboronák tanulmányozására. A mozgás egyenletei az $x F y$ mozgó koordináta rendszerben a következő összefüggéssel számolhatók, [2], [4], [6]:

$$
\theta=\omega \cdot t
$$

$A_{k}\left\{\begin{array}{l}x_{A k}=r \cos \left[(-1)^{k} \theta+k \frac{\pi}{2}\right] \\ y_{A k}=f k+r \sin \left[(-1)^{k} \theta+k \frac{\pi}{2}\right] \\ z_{A k}=-l\end{array}\right.$

$$
\begin{aligned}
& B_{k}\left\{\begin{array}{l}
x_{B k}=r \cos \left[(-1)^{k} \theta+(k+2) \frac{\pi}{2}\right] \\
y_{B k}=f k+r \sin \left[(-1)^{k} \theta+(k+2) \frac{\pi}{2}\right] \\
z_{B k}=-l
\end{array}\right. \\
& k=\left\{-\frac{n}{2}+1, \ldots, \frac{n}{2}\right\}, n \in N \\
& \text { vagy: } k \in\left\{-\frac{n}{2}, \ldots, \frac{n}{2}-1\right\}, n \in N
\end{aligned}
$$




$$
r=\frac{d}{2}
$$

ahol: $d[\mathrm{~m}]$ a müvelöeszköz tárcsájának átméröje; $\omega[\mathrm{rad} / \mathrm{s}]$ a hajtótengely szögsebessége; $l[\mathrm{~m}]$ a müvelőeszköz magassága; $k$ a müvelöeszköz sorszáma; $n$ a művelőeszközök száma, $f \quad[\mathrm{~m}] \quad$ a művelőeszközök közti osztástávolság. Megjegyzés:

- $n$ páros természtes szám,

- $f$ értéke függ a boronafog alakjától.

Az $A_{k}\left(x_{A k} y_{A k}, z_{A k}\right), B_{k}\left(x_{B k}, y_{B k}, z_{B k}\right)$ pontok pályagörbéje az $x O y$ álló koordináta rendszerben a következő transzformációs matrixxal határozható meg, [2], [4]:

$$
A, B_{x O y}=\left(\begin{array}{cccc}
1 & 0 & 0 & v_{m} t \\
0 & 1 & 0 & 0 \\
0 & 0 & 1 & 0 \\
0 & 0 & 0 & 1
\end{array}\right)
$$

A mozgásegyenletek az álló, $x O y$ koordináta rendszerben, amely az $x F y$ mozgó koordináta rendszerhez képest vm sebességgel halad $F x$ tengely irányában, 3. ábra, a következők:

$$
\begin{gathered}
\left(\begin{array}{c}
{ }^{o} x_{A k} \\
{ }^{o} y_{A k} \\
{ }^{o} z_{A k} \\
1
\end{array}\right)=A, B_{x O y} \cdot\left(\begin{array}{c}
x_{A k} \\
y_{A k} \\
z_{A k} \\
1
\end{array}\right) \\
{ }^{o} A_{k}\left\{\begin{array}{l}
{ }^{o} x_{A k}=r \cos \left[(-1)^{k} \theta+k \frac{\pi}{2}\right]+v_{m} t \\
{ }^{o} y_{A k}=f \cdot k+r \sin \left[(-1)^{k} \theta+k \frac{\pi}{2}\right] \\
{ }^{o} z_{A k}=-l
\end{array}\right.
\end{gathered}
$$

$$
{ }^{o} B_{k}\left\{\begin{array}{l}
{ }^{o} x_{B k}=r \cos \left[(-1)^{k} \theta+(k+2) \frac{\pi}{2}\right]+v_{m} t \\
{ }^{o} y_{B k}=f k+r \sin \left[(-1)^{k} \theta+(k+2) \frac{\pi}{2}\right] \\
{ }^{o} z_{B k}=-l
\end{array}\right.
$$

ahol: $v_{m}$ a munkagép haladási sebessége, $[\mathrm{m} / \mathrm{s}]$. Az összefüggésekben található jelölések a 3. ábrán követhetők.

A mozgásegyenletek grafikus képe a szakirodalomban fellelhető ábrával megegyezik, 4. ábra, tehát a (9), (10) egyenletek helyeseknek tekinthetök és alkalmasak a további vizsgálatok elvégzéséhez.

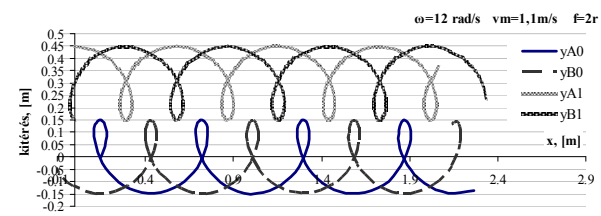

4. ábra. Forgóborona-fogcsúcsok mozgáspályái

A mozgásegyenletek segítségével meghatároztuk az általános $A_{k}\left(x_{A k} y_{A k}, z_{A k}\right)$, $B_{k}\left(x_{B k}, y_{B k}, z_{B k}\right)$ pontok pillanatnyi sebességeit és gyorsulásait.

A pillanatnyi sebességek összefüggései:

$$
\begin{aligned}
& \left\{\begin{array}{l}
{ }^{o} \dot{x}_{A k}=v_{x A k}=-(-1)^{k} r \dot{\theta} \sin \left[(-1)^{k} \theta+k \frac{\pi}{2}\right]+v_{m} \\
{ }^{o} \dot{y}_{A k}=v_{y A k}=(-1)^{k} r \dot{\theta} \cos \left[(-1)^{k} \theta+k \frac{\pi}{2}\right] \\
{ }^{o} \dot{z}_{A k}=v_{z A k}=0
\end{array}\right. \\
& \left\{\begin{array}{l}
{ }^{\circ} \dot{x}_{B k}=v_{x B k}=-(-1)^{k} r \dot{\theta} \cdot \sin \left[(-1)^{k} \theta+(k+2) \frac{\pi}{2}\right]+v_{m}(12) \\
{ }^{\circ} \dot{y}_{B k}=v_{y B k}=(-1)^{k} r \dot{\theta} \cdot \cos \left[(-1)^{k} \theta+(k+2) \frac{\pi}{2}\right] \\
{ }_{\dot{z}_{B k}}=v_{z B k}=0
\end{array}\right. \\
& \dot{\theta}=\varpi
\end{aligned}
$$

A pillanatnyi gyorsulás összefüggései: 


$$
\begin{aligned}
& \left\{\begin{array}{l}
{ }^{o} \ddot{x}_{A k}=a_{x A k}=-r \dot{\theta}^{2} \cos \left[(-1)^{k} \theta+k \frac{\pi}{2}\right] \\
o \ddot{y}_{A k}=a_{y A k}=-r \dot{\theta}^{2} \sin \left[(-1)^{k} \theta+k \frac{\pi}{2}\right] \\
{ }^{o} \ddot{z}_{A k}=a_{z A k}=0
\end{array}\right. \\
& \left\{\begin{array}{l}
{ }^{o} \ddot{x}_{B k}=a_{x B k}=-r \dot{\theta}^{2} \cos \left[(-1)^{k} \theta+(k+2) \frac{\pi}{2}\right] \\
{ }^{o} \ddot{y}_{B k}=a_{y B k}=-r \dot{\theta}^{2} \sin \left[(-1)^{k} \theta+(k+2) \frac{\pi}{2}\right] \\
{ }^{o} \ddot{z}_{B k}=a_{z B k}=0
\end{array}\right.
\end{aligned}
$$

A hajtó müvelőszerszám boronafogainak pillanatnyi sebességei és gyorsulásai az 5. ábrán, illetve 6. ábrán láthatók. A pillanatnyi értékeket $\mathrm{r}=0,15 \mathrm{~m}, \omega=12 \mathrm{rad} / \mathrm{s}$, $\mathrm{v}_{\mathrm{m}}=1,1 \mathrm{~m} / \mathrm{s}$ sajátos esetben számítottuk:

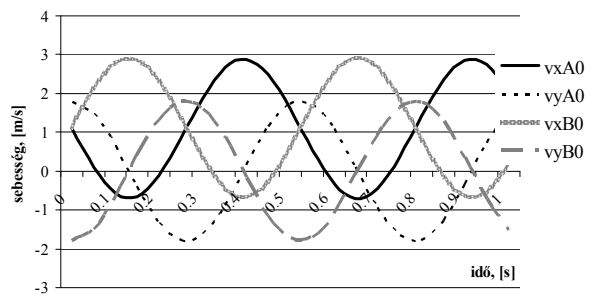

5.ábra. Forgóboronafogak pillanatnyi sebességei

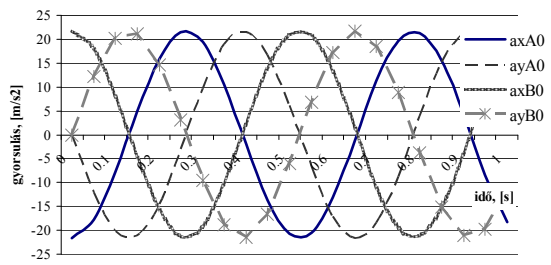

6.ábra. Forgóboronafogak pillanatnyi gyorsulásai

\section{Következtetések}

A szerszámok talajba nyúló részei a forgó és haladó mozgás együttes hatására hurkolt ciklois pályát írnak le a talaj felszíne alatt $l$ mélységben lévő vízszintes síkban. $\mathrm{E}$ mozgás jelentős keverő hatást eredményez az aprítás mellett. Emiatt nő a munkagép által felvett energia.

A dolgozatban meghatározott kinematikai egyenletek leírják a szakirodalomban fellelhető mozgáspályát, így alkalmasak az elméleti vizsgálatok elvégzéséhez. Ezen elméleti vizsgálatok a gyakorlati vizsgálatokat alapozzák.

A forgóborona kinematikai egyenletei alapján meghatározhatók a dinamikai és az energetikai egyenletek, amelyek segítségével tanulmányozható a munkagép energiaigénye.

\section{Szakirodalmi hivatkozások}

[1] Láng, Z.: A zöldség-, dísznövény- és szaporítóanyag - termesztés berendezései és gépei, Mezőgazda Kiadó, Budapest, 1999, 192-198.

[2] Máté, M.: Müszaki mechanika - kinematika, EME Kiadó, Kolozsvár, 2010, 24-38;

[3] Naghiu, Al.: Maşini şi instalaţii agricole, vol. I, Risoprint Kiadó, Kolozsvár, 2004, 192198.

[4] Papp, I.: Mechanizmusok elmélete, Scientia Kiadó, Kolozsvár, 2010;

[5] Pásztor, J., Forgó, Z.: Ásógép munkaeszközének kinematikai és dinamikai vizsgálata, Erdélyi Múzeum Egyesület, Müszaki Tudományok Szakosztálya, XIX. FMTÜ, ISSN 2067 - 6 808, 2014. március 20-21, Kolozsvár, 325-328.

http://eda.eme.ro/handle/10598/28187.

[6] Tolvaly-Rosca, F.: A számítógépes tervezés alapjai: AutoLisp és Autodesk Inventor alapismeretek, Erdélyi Múzeum-Egyesület Kiadó, Kolozsvár, 2009, 70-75. 